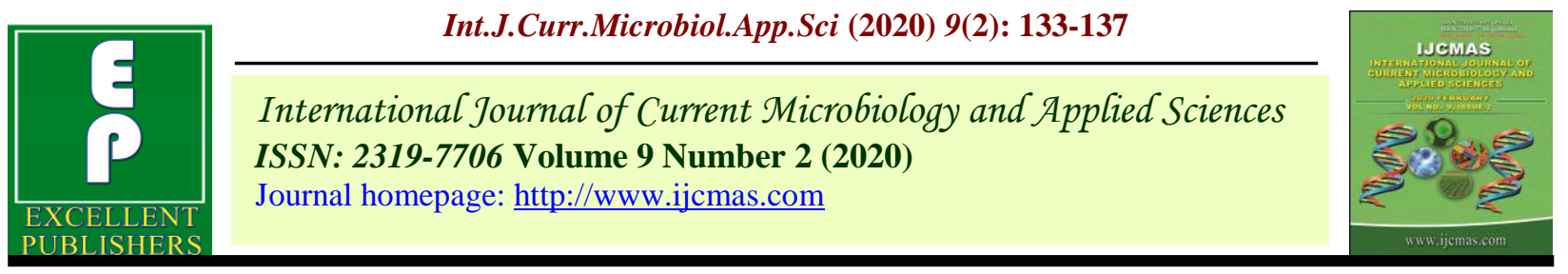

Original Research Article

https://doi.org/10.20546/ijcmas.2020.902.016

\title{
Studies on Organic Nutrient Management on Growth and Flowering of Cucumber (Cucumis sativus L.)
}

\author{
D. R. Joshiya ${ }^{1}$, J. R. Vadodaria ${ }^{1}$, B. M. Nandre ${ }^{2^{*}}$, M. K. Sharma ${ }^{2}$ and V. R. Wankhade ${ }^{3}$ \\ ${ }^{1}$ Department of Vegetable Science, College of Horticulture, Sardarkrushinagar Dantiwada \\ Agricultural University, Jagudan, India \\ ${ }^{2}$ Department of Horticulture, College of Agriculture, Sardarkrushinagar Dantiwada \\ Agricultural University, Tharad, India \\ ${ }^{3}$ Assistant Professor, Department of Horticulture, C.P. College of Agriculture, \\ Sardarkrushinagar Dantiwada Agricultural University, Sardarkrushinagar, India \\ *Corresponding author
}

Keywords

Azospirillium,

Cucumber,

Flowering, Growth, KSM, PSB and Trichoderma viride

Article Info

Accepted:

05 January 2020

Available Online:

10 February 2020

\section{A B S T R A C T}

The present investigation entitled, studies on organic nutrient management on growth and flowering of cucumber (Cucumis sativus L.) was carried out during summer-2016 at Horticulture Instructional Farm, Department of Horticulture, Chimanbhai Patel College of Agriculture, Sardarkrushinagar Dantiwada Agricultural University, Sardarkrushinagar. Total nine treatments of organic nutrients were tested in the Factorial Randomized Block Design with three replications. Treatments were evaluated on the basis of growth and flowering characteristics of cucumber. Maximum vine length at 30 and $60 \mathrm{DAS}$, number of branches per plant, leaf area per plant at $45 \mathrm{DAS}$, number of female flowers per plant and maximum per cent fruit set was recorded with treatment $50 \% \mathrm{~N}$ through castor cake $+50 \% \mathrm{~N}$ through poultry manure + biofertilizers (Azospirillium+PSB+KSM) + Trichoderma viride + neem oil.

\section{Introduction}

Cucumber is one of the most popular, quickest maturing and widely grown vegetables originated in India. The immature fruits of cucumber are used as salad and for pickling. Cucumber has great importance due to its short duration and high production potential as well as high nutritive value. FYM is principle source of organic matter in our country. Neem cake is a potential source of organic manure. Poultry manure contains about 3.30 per cent $\mathrm{N}, 0.63$ per cent $\mathrm{P}_{2} \mathrm{O}_{5}$ and 1.40 per cent $\mathrm{K}_{2} \mathrm{O}$ (Gaur et al., 1982). Castor cake is rich source of $\mathrm{N} 4.5$ per cent, $\mathrm{P}_{2} \mathrm{O}_{5} 1.8$ per cent, $\mathrm{K}_{2} \mathrm{O} 1.0$ per cent and micronutrients 
(Yawalkar et al., 1996). Use of FYM alone or in combination with organic nutrients helps in proper supply of essential plant nutrients and improve the physico-chemical properties, increases water holding capacity and encourages the soil microbial activities and maintains soil health. Many microorganisms inhabiting soil/rhizosphere play an important role in solubilization of bound form of soil minerals and enhance the availability of nutrients in the soil for plant growth and development. These plant growth-promoting rhizobacteria, including $\mathrm{N}_{2}$-fixing, phosphate solubilizing bacteria, potassium solubilizing microorganisms are being used as biofertilizers to minimize health hazards caused by the use of chemical fertilizers. In recent years, free living bacteria (Azotobacter), associate (Azospirillum) and symbiotic (Rhizobium) bacteria, phosphate solubilizing (Bacillus megaterium, $B$. polymyxa and $P$. Striata) and the potassium solubilizing microorganisms (KSMs) are gaining much popularity. Application of biofertilizer encouraged plant growth and productivity of many crops. Utilization of biofertilizers in the form of microbes is very successful in minimizing chemical fertilizer to half of the recommended dose.

\section{Materials and Methods}

Four organic manures (FYM, poultry manure, neem cake and castor cake) in various combinations with bio-fertilizers (Azospirillium+PSB+KSM) and Trichoderma viride were tried. Total nine treatments viz., $\mathrm{T}_{1}(50 \% \mathrm{~N}$ from FYM $+50 \% \mathrm{~N}$ from Poultry Manure), $\mathrm{T}_{2}(50 \% \mathrm{~N}$ from Neem cake $+50 \%$ $\mathrm{N}$ from Poultry Manure), $\mathrm{T}_{3}(50 \% \mathrm{~N}$ from Castor cake $+50 \% \mathrm{~N}$ from Poultry Manure), $\mathrm{T}_{4}\left[\mathrm{~T}_{1}+\right.$ Biofertilizer (Azospirillum $+\mathrm{PSB}+$ $\mathrm{KSM})], \mathrm{T}_{5}\left[\mathrm{~T}_{2}+\right.$ Biofertilizer (Azospirillum + $\mathrm{PSB}+\mathrm{KSM})], \quad \mathrm{T}_{6}\left[\mathrm{~T}_{3}+\right.$ Biofertilizer (Azospirillum $+\mathrm{PSB}+\mathrm{KSM})], \mathrm{T}_{7}\left(\mathrm{~T}_{4}+\right.$ Trichoderma viride + Neem oil $), \mathrm{T}_{8}\left(\mathrm{~T}_{5}+\right.$
Trichoderma viride + Neem oil $)$ and $\mathrm{T}_{9}\left(\mathrm{~T}_{6}+\right.$ Trichoderma viride + Neem oil). All the treatments were applied at the time of field preparation. Observation for growth and flowering were recorded and the mean data were subjected to statistical analysis following analysis of variance technique (Panse and Sukhatme, 1985).

\section{Results and Discussion}

\section{Effect of organic nutrients on growth parameters}

Data in Table 1 showed significant difference for growth parameters among different levels of organic nutrient.

Significantly maximum vine length (70.87 $\mathrm{cm})$ and $(428.06 \mathrm{~cm})$ at 30 and 60 DAS respectively, number of branches per plant (6.01) and leaf area $\left(2187.89 \mathrm{~cm}^{2}\right)$ was recorded with application of 50 per cent $\mathrm{N}$ from Castor cake +50 per cent $\mathrm{N}$ from Poultry Manure + Biofertilizer (Azospirillum $+\mathrm{PSB}+\mathrm{KSM})+$ Trichoderma viride + Neem oil $\left(\mathrm{T}_{9}\right)$.

The increase in vine length at 30 DAS might be due to improve moisture availability which enhanced nutrients release to plant for increased vine growth. Similar variation in respect to main vine length due to different organic manures were previously reported by Karuppaiah and Kathiravan (2006), Prabhu et al., (2006), Eifediyi et al., (2010) and Eifediyi and Remison (2010) in cucumber.

Increase the vine length at $60 \mathrm{DAS}$ might be due to the application of organic manure along with biofertilizer is necessary to increase the content of organic matter, maintain the nutrients balance for crops and improve the physical and chemical properties of the soil. 
Table.1 Effect of organic nutrient on growth and flowering parameters

\begin{tabular}{|c|c|c|c|c|c|c|c|c|}
\hline Organic nutrient & $\begin{array}{c}\text { Vine } \\
\text { length } \\
\text { at } 30 \\
\text { DAS } \\
\text { (cm) }\end{array}$ & $\begin{array}{c}\text { Vine } \\
\text { length } \\
\text { at } 60 \\
\text { DAS } \\
(\mathrm{cm})\end{array}$ & $\begin{array}{c}\begin{array}{c}\text { Number } \\
\text { of } \\
\text { branches }\end{array} \\
\text { per plant }\end{array}$ & $\begin{array}{c}\text { Leaf area } \\
\text { per plant } \\
\text { at } 45 \text { DAS } \\
\left(\mathrm{cm}^{2}\right)\end{array}$ & $\begin{array}{c}\text { Days } \\
\text { taken to } \\
\text { flower } \\
\text { initiation }\end{array}$ & $\begin{array}{c}\text { Number } \\
\text { of male } \\
\text { flowers } \\
\text { per } \\
\text { plant }\end{array}$ & $\begin{array}{c}\text { Number } \\
\text { of female } \\
\text { flowers } \\
\text { per plant }\end{array}$ & $\begin{array}{l}\text { Per cent } \\
\text { fruit set }\end{array}$ \\
\hline $\begin{array}{l}\mathrm{T}_{1}=\mathbf{5 0 \%} \mathrm{N} \text { from } \mathrm{FYM}+\mathbf{5 0 \%} \mathrm{N} \text { from } \\
\text { Poultry Manure }\end{array}$ & 29.94 & 325.87 & 3.20 & 941.34 & 35.57 & 68.70 & 17.67 & 41.05 \\
\hline $\begin{array}{l}\mathrm{T}_{2}=50 \% \mathrm{~N} \text { from Neem cake }+50 \% \mathrm{~N} \\
\text { from Poultry Manure }\end{array}$ & 39.46 & 338.36 & 3.20 & 1212.75 & 32.28 & 70.63 & 18.50 & 45.27 \\
\hline $\begin{array}{l}\mathrm{T}_{3}=50 \% \mathrm{~N} \text { from Castor cake }+50 \% \mathrm{~N} \\
\text { from Poultry Manure }\end{array}$ & 43.52 & 344.64 & 3.84 & 1227.58 & $32 . .03$ & 73.67 & 18.73 & 46.95 \\
\hline $\begin{array}{l}T_{4}=T_{1}+\text { Biofertilizer (Azospirillium }+ \text { PSB } \\
+ \text { KSM) }\end{array}$ & 52.08 & 355.04 & 4.44 & 1312.64 & 31.02 & 78.07 & 19.93 & 51.17 \\
\hline $\begin{array}{l}\mathbf{T}_{5}=\mathbf{T}_{2}+\text { Biofertilizer (Azospirillium }+ \text { PSB }+ \\
\text { KSM) }\end{array}$ & 58.04 & 382.92 & 1.94 & 1500.74 & 30.46 & 85.00 & 21.63 & 54.54 \\
\hline $\begin{array}{l}\mathbf{T}_{6}=\mathbf{T}_{3}+\text { Biofertilizer (Azospirillium }+ \text { PSB }+ \\
\text { KSM) }\end{array}$ & 57.04 & 412.05 & 3.61 & 1589.70 & 30.26 & 93.90 & 23.53 & 57.91 \\
\hline $\mathbf{T}_{7}=\mathbf{T}_{4}+$ Trichoderma viride + Neem oil & 63.67 & 427.22 & 5.61 & 1793.61 & 29.97 & 99.70 & 24.13 & 62.96 \\
\hline $\mathbf{T}_{8}=\mathrm{T}_{5}+$ Trichoderma viride + Neem oil & 66.61 & 424.76 & 5.96 & 2187.89 & 29.87 & 100.77 & 24.53 & 64.65 \\
\hline $\mathbf{T}_{9}=\mathbf{T}_{6}+$ Trichoderma viride + Neem oil & 70.87 & 428.06 & 6.01 & 1252.84 & 29.53 & 101.77 & 25.43 & 66.34 \\
\hline S.Em. \pm & 1.61 & 14.01 & 0.24 & 73.13 & 0.93 & 2.00 & 0.59 & 2.11 \\
\hline C.D. at $5 \%$ & 4.63 & 40.28 & 0.71 & 210.16 & 2.68 & 5.75 & 1.69 & 6.06 \\
\hline C. V.\% & 7.39 & 8.99 & 14.38 & 12.38 & 7.34 & 5.71 & 6.71 & 9.48 \\
\hline
\end{tabular}


The positive effect of organic manure on growth parameters obtained in this study was supported by Prabhu et al., (2006) Eifediyi et al., (2010) and Eifediyi and Remison (2010) in cucumber.

Significantly maximum number of branches per plant similar results was earlier reported by Karuppaiah and Kathiravan (2006), Eifediyi and Remison (2010) and Anjanappa et al., (2012) in cucumber. Significantly maximum leaf area similar results are in close accordance with the findings of Karuppaiah and Kathiravan (2006) in cucumber.

\section{Effect of organic nutrient management on flowering}

Data in Table 1 showed significant difference for flowering parameters among different levels of organic nutrient.

Significantly minimum days taken for initiation of flowering (29.53), maximum number of female flowers per plant (25.43) and per cent fruit set (66.34) were recorded with application of $50 \% \mathrm{~N}$ from castor cake + $50 \% \mathrm{~N}$ from poultry manure + biofertilizers (Azospirillum + PSB + KSM $)+$ Trichoderma viride + neem oil $\left(\mathrm{T}_{9}\right)$, which was statistically at par with treatment $\mathrm{T}_{8}, \mathrm{~T}_{7}, \mathrm{~T}_{6}, \mathrm{~T}_{5}, \mathrm{~T}_{4}$ and $\mathrm{T}_{3}$. Early flowering under the influences of integrated supply of nutrients through organic manures and biofertilizers might be due to better soil health which improves flowering parameters Anjanappa et al., (2012) in cucumber. The findings are in the accordance with the results of Singh et al., (2012) and Anjanappa et al., (2012) in cucumber.

Significantly minimum number of male flowers per plant (68.70) was recorded with application of $50 \% \mathrm{~N}$ from FYM $+50 \% \mathrm{~N}$ from poultry manure $\left(\mathrm{T}_{1}\right)$ and it was remain statistically at par with treatment $T_{2}$ and $T_{1}$. Similar trend in variation in number of male flowers per plant due to organic manure was earlier reported by Karuppaiah and Kathiravan (2006), Anjanappa et al., (2012) in cucumber and Thriveni et al., (2015) in bitter gourd.

The increase in number of female flower due to application of different organic manure was earlier reported by Karuppaiah and Kathiravan (2006) in cucumber, Mulani et al., (2007) in bitter gourd, Anjanappa et al., (2012) in cucumber Thriveni et al., (2015) in bitter gourd.

Maximum per cent fruit set similar trend of variation in fruit setting per cent due to sources of different organic manure and biofertilizer were earlier reported by Karuppaiah and Kathiravan (2006) in cucumber.

On the basis of field experimentation, it was concluded that to obtain better growth and flowering of cucumber apply $50 \%$ castor cake $+50 \%$ poultry manure + bio fertilizers (Azospirillum + PSB + KSM $)+$ Trichoderma viride + Neem oil.

\section{References}

Anjanappa, M., Venkatesha, J. and Kumara, B.S. (2012). Growth, Yield and quality attributes cucumber (cv. Hasan local) as influenced by integrated nutrient management grown under protected condition. Vegetable Science. 39 (1): 47-50.

Eifediyi, E.K. and Remison, S.U. (2010). Growth and yield of cucumber (Cucumis sativus L.) as influenced by farm yard manure and inorganic fertilizer. Journal of Plant Breeding and Crop Science. 2 (7): 216-220.

Eifediyi, E.K., Remison, S.U. and Okaka, V.B. (2010). Effect of farm yard manure on the dry matter content of two 
cucumber varieties. Nature and Science. 8 (5): 16-22.

Gaur, A.C., Sadashivam, K.V., Mathu, R.J. and Maer, S.P. (1982). Role of mesophytic fungus in composting. Agricultural Waste. 4: 453-460.

Karuppaiah, P. and Kathiravan, J. (2006). Effect of tillage, manures and biofertilizers on the performance of cucumber (Cucumis sativus L.) under rice fallow condition. Plant Archives. 6 (2): 573-576.

Mulani, T.G., Musmade, A.M., Kadu, P.P. and Mangave, K.K. (2007). Effect of organic manures and biofertilizer on growth, yield and quality of bitter gourd cv. (Phule Green Gold). J-soil science and crops. 17 (2): 258-261.

Panse V.G. and Sukhatme P.V. (1985). Statistical methods for agricultural workers, I.C.A.R. pub. New Delhi. 97123.
Prabhu, M., Natarajan, S., Srinivasan, K. and Pugalendhi, L. (2006). Integrated nutrient management in cucumber. Indian Journal of Agricultural Research. 40 (2): 123-126.

Singh, D.P., Mishra, U.C., Prakash, H.G. and Mishra, Omita (2012). Role of organic farming on yield and economics of bottle gourd after vegetable pea. International Journal of Agricultural Sciences. 8 (1): 165-167.

Thriveni, V., Mishra, H.N., Pattanayak, S.K., Sahoo, G.S. and Thomson, T. (2015). Effect of inorganic, organic and biofertilizers on growth, flowering, yield and quality attributes of bitter gourd (Momordica charantia L). International Journal of Farm Science. 5 (1): 24-29.

Yawalkar, K.S., Agameal, J.P and Bokde, S. (1996). Manures and Fertilizer. Agri. Horticultural Publishing House. p. 73.

\section{How to cite this article:}

Joshiya, D. R., J. R. Vadodaria, B. M. Nandre, M. K. Sharma and Wankhade, V. R. 2020. Studies on Organic Nutrient Management on Growth and Flowering of Cucumber (Cucumis sativus L.). Int.J.Curr.Microbiol.App.Sci. 9(02): 133-137. doi: https://doi.org/10.20546/ijcmas.2020.902.016 